\title{
Navigating the City and the Workplace: Migrant Female Construction Workers and Urban (Im)Mobilities
}

\author{
Rebecca Bowers, London School of Economics, United Kingdom
}

\begin{abstract}
While their labour shapes the growing cityscape, migrant construction workers often remain invisible - not only to property developers and consumers but also to the state. For female workers, this is compounded by gender-based discrimination within the industry. Utilising ethnographic data, this article explores how women working in construction in Bengaluru, India, both experience and strive for mobility. It provides a multi-sited analysis to establish the ways in which intersectionality between employment conditions, the urban environment and gender norms may inhibit or facilitate urban mobility for migrant female workers. Few ethnographic studies have attended to women's experiences of intermingled work/accommodation sites within the industry, although the practices and outcomes produced by the blurring of such boundaries provides fertile ground for analysis. While the article confirms the enduring nature of discrimination experienced by women in the construction industry, it also attends to the ways in which female workers were able to utilise spaces of exploitation. I conclude that precarious livelihoods may not at first glance yield enduring or substantive beneficial outcomes for those compelled to undertake them, but they are nevertheless productive - allowing for the maintenance and fulfilment of aspirations which may not reside within the urban domain.
\end{abstract}

\section{KEYWORDS}

circular migration; labour; gender; women; construction work

\section{Introduction}

The real estate industry in Bengaluru - located in Karnataka state in southwest India - upon which the foundations of urban growth tentatively rest, is largely built upon speculative practices which generate precarity (Goldman, 2011; Cross, 2014; Searle, 2016). The outcome of such practices is keenly felt by the city's migrant construction workers, to whom much of the industry's financial and physical risk is devolved in cost-cutting exercises, while being simultaneously excluded from its capital gains. Migrant workers often remain invisible in the cities in which they live and work increasingly unable to gain a foothold in the urban environment (Roy, 2003; Smith and Pun, 2006; Pun and Huilin, 2010; Amrith, 2011; Breman, 2016). Due to a lack of wider-reaching local networks, created in part by residence in employer-provided accommodation, they are largely unable to draw upon the same means of collective organisation as settled workers. Employers thus not only express a preference for migrant labour but, through their actions, perpetuate migrant precarity.

Although there is a growing body of literature on the exploitative conditions of construction work in India (Pattenden, 2012; Picherit, 2012; Parry, 2014), the experiences of migrant female construction workers remain largely underrepresented in qualitative studies. Moreover, few 
ethnographic studies have attended to women's experiences of intermingled work/accommodation sites within the industry, although the practices and outcomes produced by the blurring of such boundaries provide fertile ground for analysis, as Chris Smith and Pun Ngai (2006) have illustrated concerning migrant labour dormitories in China. With that in mind, this article considers the oftenomitted narratives of the status of a largely invisible portion of Bengaluru's populace: the women and their families who travel to and from the city to undertake construction work. In doing so, it engages with the growing but limited body of scholarship concerning migrant labour and gendered mobility among female construction workers (Suri, 2000; Jatrana and Sangwan, 2004; Dalmia, 2012; Parry, 2014). Expanding on these studies, this article provides a multi-sited analysis to establish the ways in which intersectionality between employment conditions, the urban environment and gender norms may inhibit or facilitate urban mobility for migrant female workers.

The main research question focuses on how migrant female construction workers experience mobility, given the intersectional and ostensibly restrictive nature of gender norms and employment and living conditions within the industry. It attends to how the precarity of construction work and the city itself is endured and contested by rural migrant women and their families. Acknowledging the role of gender, which invariably intersects with these experiences, the article unpacks the ways in which construction work embodies a further extension of the domestic sphere within which women's labour remains devalued and concealed. In doing so, it explores how construction work and its concomitant spaces interact with and shape women's navigations through the urban environment and the industry itself, forming part of the wider discussion concerning issues and strategies of mobility for informal-sector women workers (Nadgijm, 2005; Baruah, 2010; Agarwala, 2013; Kamath and Ramanathan, 2017; A. Shah et al., 2018). While the article confirms much of the findings of this literature concerning the discrimination experienced by women in the construction industry, it also attends to the ways in which female workers have been able to utilise spaces of exploitation - ranging from collective forms of organisation to the fulfilment of rurally based lives and aspirations.

A contextual analysis of the construction industry in India and women workers is provided below, followed by a brief introduction of the ethnographic setting and both field sites. The article is structured into three central themes: labour migration and control; spatiality and residence; and gender. Highlighting the critical centrality of labour accommodation and employment conditions to urban mobility, I draw on data from two separate field sites, collected during doctoral fieldwork and research work in 2015 and 2016. While both cases provide relatively typical examples of migrant workers from the Andhra-Karnataka border regions, they were selected to illustrate how small and yet substantive differences in urban mobility may evolve from employment conditions over time. Although each group spent the majority of their time in the city, there were significant discrepancies revealed in forms of social, fiscal, vocational and educational mobility. However, despite the fact that the inhabitants of the second field site experienced a more stable form of urban residence (a less common occurrence within the industry), their overall sentiments towards urban life were not dissimilar to that of the first group - attesting to the enduring liminality experienced by many families undertaking circular migration in India.

\section{The Present Scenario: Rural to Urban Migration, Construction Work and Women}

For the increasing number of landless and land-poor families in rural India, there are limited 
options to sustain lives and livelihoods in the village. ${ }^{1}$ Available work primarily lies within the country's vast construction sector which, despite its low-value productive output in terms of economic reward and mobility, constitutes the main alternative to agricultural work (Institute of Human Development, 2014; Jain, 2016). In Bengaluru and across India, seasonal migration to and from construction work is widespread, although in the scenario of more frequent drought conditions, many workers are spending increasing amounts of time in the city, returning to the village only for significant lifecycle events and festivals when they are able.

While cyclical rural to urban migration is prevalent across India, women's interstate labour migration to the south from northern India is comparatively scarce, due to differing gender norms (De Haan, 1999; Srivastava and Jha, 2016). As a result, the composition of female workforces on construction sites in the southern states primarily consists of inter- and intra-state migrants who typically have travelled with their families for work, often with children. Nevertheless, throughout India as a whole, construction work remains the second-largest employer of women in the country behind agriculture (Madhok, 2005; Devi and Kiran, 2013; Rahul, 2014). As is the case with most forms of manual work, it is dominated by Dalit (lower caste) and Adivasi (indigenous) women (Madhok, 2005; Institute of Human Development, 2014; Srivastava and Jha, 2016). Approximations have placed the proportion of women undertaking construction at anywhere between 30 and 50 per cent (Mobile Crèches, 2011; Devi and Kiran, 2013; Rahul, 2014; Khanijow, 2018; WIEGO, 2019) of the total estimated forty-million-strong workforce (CIDC, 2012; Salve, 2013; Bhalla, 2015; Khanijow, 2018). ${ }^{2}$ Statistical evidence suggests a substantial increase in women joining the industry since the 1980s (Rahul, 2014; Srivastava and Jha, 2016).

Industry-wide, both migrant and local women endure similar forms of discrimination, although for the former, these are often exacerbated by the intersection of gender prejudices with already restrictive migrant labour employment conditions. Female workers are paid between a third to a half less wages than men for performing the same roles (Devi and Kiran, 2013; Bhalla, 2015; WIEGO, 2019). Moreover, women are often underemployed or the first to be laid off, with a recent report claiming their share of employment has been decreasing since 1983 (Srivastava and Jha, 2016). Perhaps the most significant and overt form of discrimination of all is the fact that female workers are unable to ascend in the industry (V. Shah, 1996; Vaid, 1999; Parry, 2014; Breman, 2016). Sexual harassment and exploitation (particularly at the hands of employers) are common but widely under-reported (Parry, 2014; Patel and Pitroda, 2016; Sany, 2016; Action Aid, 2017).

\section{Ethnographic setting}

The informants in this paper hail from Andhra Pradesh and north-eastern Karnataka, separated only by an hour's train ride across the state border. Both groups of workers experience the same socio-economic conditions that require them to undertake construction in the city as many other

\footnotetext{
${ }^{1}$ According to Jan Breman, land availability in India is shrinking to unsustainable levels in rural areas. As a result, "more than eight out of ten agrarian producers in the subcontinent have holdings of less than 2.5 acres, less than is minimally required for their household livelihood" (Breman, 2016: 43).

2 The Institute of Human Development (2014: 53) has indicated that women are often undercounted in Labour Force Participation Rate surveys, which may explain the vast discrepancy in these figures.
} 
scheduled caste ${ }^{3}$ agricultural workers in India - increasing drought, shrinking plots of land, rising debt and insufficient crop yields. They regularly move between their villages and the city, undertaking what was referred to in Kannada ${ }^{4}$ as gaardi or coolie kelsa (concrete moulding and helper work) in Bengaluru, Karnataka, some nine hours away by train. Known as India's "silicon valley", Bengaluru provides a prime example of unchecked urbanisation, having witnessed exponential growth in the last three decades (Kerur, 2011). Subject to the shifting visions and desires of elites and global investors (Gopalan, 2010; Goldman, 2011), the erstwhile garden city, once famous for its lakes and green spaces, is now under-planned and over-populated, to the extent that some are now questioning its longevity (Lakshmi, 2013; Bhasthi, 2017).

\section{Site I: Office development, southern Bengaluru}

Though apparently nearing completion, Praveen's ${ }^{5}$ project, a four-storey office building in the south of the city, was covered in bamboo scaffolding, ${ }^{6}$ appearing to be little more than a hollow shell supported by a thicket of wooden stilts. The building's floors were bare and strewn with detritus, and the rough unplastered walls were inscribed with various children's (and adult's) drawings, some signifying luck and fortune (a chalk peacock adorned a pillar), others the scribbled whims of young minds. There were approximately twenty workers on site. As is frequent across construction sites in India, worker residences were spatially separated by region of origin. Two families from a village in Adoni (a severely drought-stricken region close to the border with Karnataka in Andhra Pradesh) lived side-by-side in huts built of breeze-blocks adjacent to the site, while the two families from Gulbarga (a region of North Karnataka) dwelled in makeshift tents on the ground floor. All families had young children with them, meaning there were at least eleven children on site; this number fluctuated over time, as some went home and others arrived. The single men from the northern states (Bihar, Jharkhand and Uttar Pradesh) lived upstairs (Figure 1). Empty rooms were used for shelter, and corners screened off for privacy with the ubiquitous blue tarpaulin sheets which constituted many migrant homes across the city.

Hemavathi and Lingamma, two female workers in their twenties, had been working for Praveen for a number of years, moving from site to site with each new development, and returning to the village whenever they could. They resided with their husbands and two children in two small breeze-block huts erected from materials taken from the site. The cramped space and poor ventilation made cooking inside hazardous as the huts quickly filled up with the dark, choking smoke of wood and kerosene. Inches from the walls was the rubbish dump for surrounding offices and apartments and the parking spaces for residents and office workers. Water was provided in large plastic bottles by the neighbouring office block, owned by the same company. Any further sanitation facilities were non-existent and workers washed their clothes in a small pollution-choked stream at the back of the site.

\footnotetext{
${ }^{3}$ Scheduled caste is the lowest in the caste hierarchy; they are also known as "Dalits" and previously as "untouchables". They remain strongly discriminated against in many contexts and continue to provide the majority of India's manual labour, undertaking the most undesirable and dangerous jobs.

${ }^{4}$ Kannada is the language of Karnataka state, although some residents of the Andhra Pradesh-Karnataka border also speak it.

5 Praveen (actual name withheld) is a property developer and one of my informants.

${ }^{6}$ Bamboo is a traditional material for scaffolding although many sites have phased this out and replaced it with metal due to safety concerns. It is susceptible to shrinking and slipping out of the knots binding the framework together, proving dangerous for workers.
} 


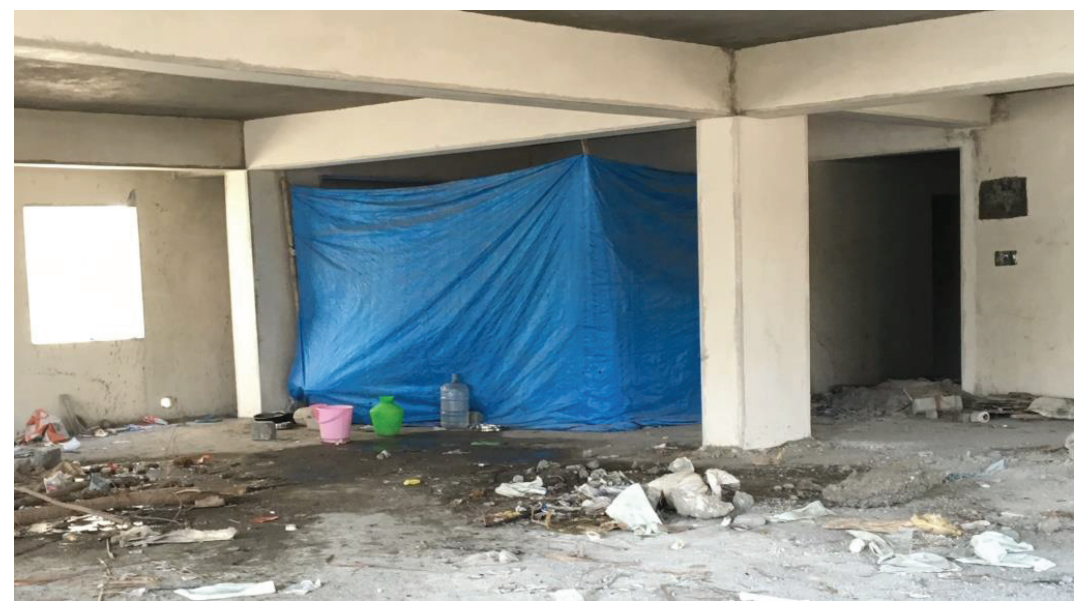

Figure 2.

Privacy screen and makeshift dwelling for single male workers on Praveen's site

\section{Site II: The Thimmaiah labour settlement, northern Bengaluru}

Approximately sixteen miles north of Praveen's site, the Thimmaiah university and hospital complex is situated. In the daytime, the sprawling seventy-acre campus is the site of ceaseless mechanical and human activity as the two-decade-long construction activity continues. There were around 250 workers present at any one time, hailing from a multitude of states. Among the workers were around thirty women, primarily from southern regions of India. The women wore bright yellow helmets denoting their status as helpers; the primary function of these helmets was to enable the women to carry materials such as bricks on their heads rather than for safety (Figure 2). They hailed from Raichur, a drought-stricken state in northern Karnataka. The older women in their thirties had been travelling to and from the campus and settlement for up to eight years, while the youngest in the group had been coming for just one year, although some family members had been working there for over a decade. All of the women had travelled with their families, via their local maistri (labour contractor), to whom one of the women was married.

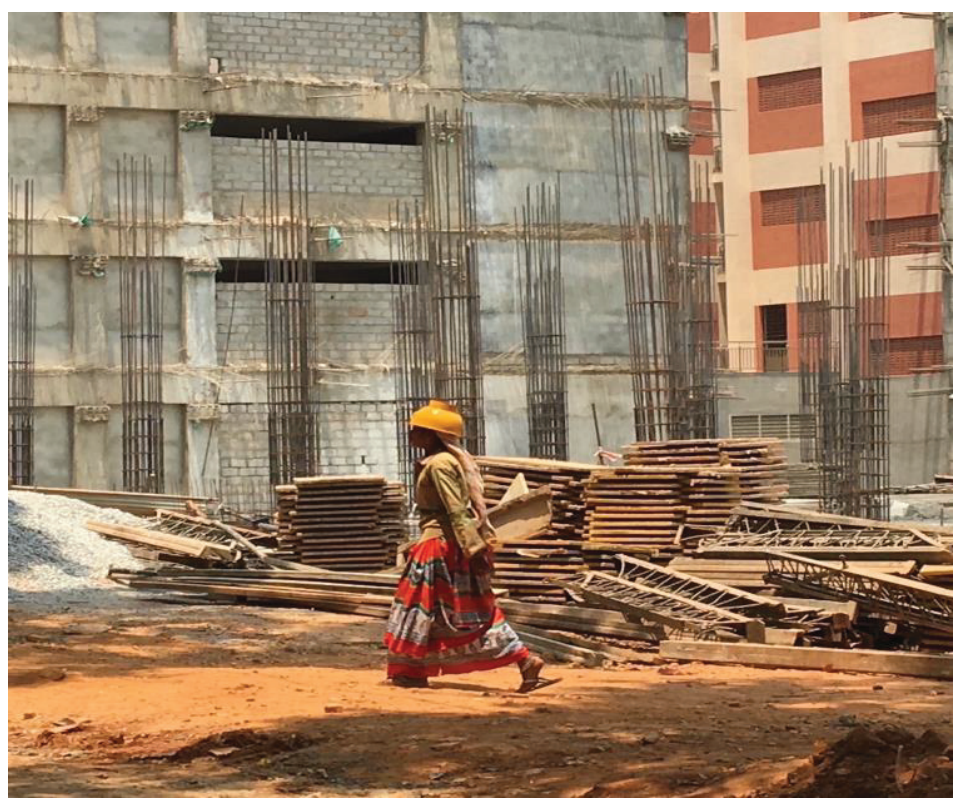

Figure 3. Female worker on Thimmaiah campus site 
The primary settlement I visited consisted of twelve women workers and their families who were from the same village. Unusually for female migrants in this scenario, not all were married, with a number of younger women accompanying their kinsfolk to work in the city. The sites consisted of rows of tin and concrete sheds arranged by the construction company, and the land was provided by the university where work was taking place. Residents had approximately four hours of electricity in the evenings, and water was delivered weekly by a tanker paid for by the company. In the growing heat of the summer, when it reached 38 degrees, the tin shacks became unbearable and the women would sit outside on the raised concrete slabs that flanked their doorways, oiling and braiding hair, chewing betel and chopping vegetables while chatting.

\section{Labour Migration and Control}

In construction, migrant workforces primarily consisting of landless, lower-caste demographics are increasingly preferred by employers since they are cheaper and deemed more exploitable (Breman, 1996, 1999, 2016; A. Shah et al., 2018). This increasingly proletarianised and mobile demographic is often denied full citizenship rights (Solinger, 1999; Ong, 2006; Amrith, 2011). In Bengaluru, this can be witnessed via the frequent lack of regard for migrant workers' most basic welfare, including the deaths of migrant construction workers from cholera due to the lack of safe drinking water and adequate sanitation in labour camps (Ceresna-Chaturvedi and Kumar, 2015; Shruthi, 2017).

Regardless of scale, all employers used the services of middlemen, absolving them of any direct responsibility for worker welfare. As one informant put it; "If you have a labour contractor, it's on his head; if you don't have one, it's on yours". Companies drew upon varying scales of maistris. Some were workers who would enlist their fellow villagers (and kin) to join them, while bigger companies hired larger-scale labour contractors able to draw from vast regional networks. In these instances, companies would try to retain their maistris, incentivising them to ensure that labour flows remained uninterrupted. Maistris at larger sites were expected to maintain onsite discipline and surveillance, paying off local authorities in the event of trouble and fending off competing companies looking for labour.

Maistris also intervened in "domestic disputes", including sexual harassment and domestic violence, although due to their association with the sexual exploitation of women workers they were also at the centre of accusations and rumours themselves (Parry, 2014). Women workers thus had little recourse to justice, let alone protection, as a company owner corroborated: 'They don't get much of protection from the contractor or the builders, and the builders doesn't [sic] give a fuck, you know?" As such attitudes iterate, many interlocutors working in real estate remained largely disengaged from the welfare of workers, whom they deemed untrustworthy. "If you show your soft side, they tend to take advantage", Praveen, the company owner of the development where Hemavathi and Lingamma worked and resided, declared. Such views were also used to justify violent methods of maintaining worker "discipline" and poor living conditions industrywide.

While workers might also be sourced from other sites, or from outside of train and bus stations, Praveen and other informants had cultivated their own labour networks throughout the years, preferring to use the same maistris and workers where possible. For this reason, while there is no permanent employment for those undertaking coolie or cement work within the field of construction in India, some workers were bound in long-term relationships with particular sites and employers. For the workers on the Thimmaiah campus managed by Sriram Construction, work was seemingly plentiful due to the continuing expansion of the campus. Gangamma, a worker in her thirties, attested: "They keep calling people from my village to come and work here. For the past fifteen years, people from our village have been coming and staying here”. Such statements 
also go some way towards debunking the trope commonly used by employers of unreliable migrant workforces prone to leaving at any time - which the industry itself had cultivated. As Searle (2016: 225) notes, "the image of the fickle migrant that contractors have painted ... obscures the use of 'transience' to Indian developers and contractors".

Since Sriram Construction had been undertaking building works on the Thimmaiah site for over a decade, they had made some investment in worker residences. As the Managing Director was keen to stress, "The workers are our family". However, there were signs at times that freedom in the labour camps was not always guaranteed. David, a local and one of the company's main labour contractors, had regular access to the camp, often turning up on site whenever I was there and reminding me not to stay too late since the outside wall to the compound was sealed off at night, purportedly for the workers' protection. In these ways and more, for "workers 'living at work' ... management agents could prescribe controls and lifestyle choices in a way not possible where there is a separation between home and work" (Smith and Pun, 2006: 1465). David thus visited the site whenever he wanted, regulating the presence of outsiders and, at night, the movement of workers.

As Jonathan Pattenden (2012: 175) found in his research of migrant construction workers in the city, bigger companies tended to pay less but provided more amenities. While the workers on Thimmaiah campus were paid less than local workers or those on Praveen's site - the difference was between fifty to one hundred rupees a day - they did have a greater number of working days, which made up for this. In the case of the Thimmaiah campus, regular employment was in itself a form of urban patronage, allowing the company to secure worker's loyalties and to meet long-term goals of project completion while managing to make considerable savings on labour. At the same time, it also kept the workers in a single location of its choosing and thus was able to monitor their linkages with the city and the local union. Significantly, although David himself was a union area leader, not one of the workers from the settlement had any knowledge of the union or the state construction workers' welfare board, which actively employed unions to register workers. Local figures and maistris such as David thus had the potential to function as gatekeepers to further mobility for migrant workers, while simultaneously withholding it. In this way, keeping workers on site (or in labour camps) was a further means used by employers to retain them, without having to formalise employment, or facilitate additional rights to the city.

Many of Praveen's workers had been with him on a long-term basis since the company's establishment eight years ago. The nature of this lengthy relationship was used to justify the deferment of payments, which may also serve as an effective method in retaining workers, in opposition to prior strategies of advancing wages (Parry, 2014; Breman, 2016). "Sometimes if I can't mobilise payments for that week I make sure I give it for the next week.... So, they know all about that, they're very flexible, they understand", Praveen told me. However, the indicated consent of this relationship was challenged when I visited the site one day to find activities had ground to a halt. Since they hadn't been paid in two weeks, the workers, angered by the stalling of their anticipated return to the village for Ugadi, ${ }^{7}$ had collectively gone on strike.

While the spaces of on-site accommodation and labour camps often exclude the presence of unions and non-governmental organisations, the above example also attests to the capacity of selforganisation among migrant workers in the growing face of exploitation (Smith and Pun, 2006; Kamath and Ramanathan, 2017; Jayaseelan Raj, 2018). However, as Smith and Pun (2006: 1469) note concerning the dormitory labour regimes in China, "it seems that protests have structural

\footnotetext{
${ }^{7}$ Ugadi is a major festival in the states of Andhra and Karnataka, marking the new year, the undertaking of new projects and, significantly for those in agriculture, the heralding of the harvest season.
} 
limitation and specificities, and these condition the form and nature of these protests". Since finding work elsewhere could have meant losing their accommodation, for Hemavathi and Lingamma - who had their young children in tow and were hundreds of miles from home - the leverage they were able to employ remained limited. In this way, while the close quarters of accommodation on the worksite might foster forms of worker mobility and solidarity, it simultaneously restricted others. As one informant confirmed, "They don't know the city and they are a bit scared and they don't leave the work space ... and they stick to you. That is the whole game point". For those owed considerable back pay and with fewer connections in the city, there was thus little recourse to recover wages except by waiting it out.

\section{The Determinants of Urban Mobility: Spatiality and Residence in Bengaluru}

With the terms of entry to and residence within Bengaluru now established, this section explores the ways in which female workers both experience and perceive the city, and how gender norms and accommodation may influence these. For many families, years of labour in Bengaluru's construction industry produced no readily attainable pathway from rural to urban settlement, nor was this necessarily desired. As Jan Breman (2016: 194) states, "migrants realize all too well their status as transient workers is tolerated as long as their labour power remains in demand but is experienced as a nuisance by citizens and even more so by public servants". It was perhaps for these reasons that workers such as Hemavathi and Lingamma, whose only interactions I witnessed with the residents of the surrounding apartments were criticisms regarding their children's behaviour, expressed little desire to settle in Bengaluru.

Even for groups of workers long settled in Bengaluru, their levels of urban mobility varied considerably and was largely tied to housing. Prior housing colonies built to accommodate the poor (and ensure urban vote banks) were now a rarity, particularly as cheaper labour flooded in from further afield. Moreover, the city's inhibitive rental deposits (which were a minimum of ten months' rent up-front for all prospective tenants regardless of income, location or vocation) made it difficult for even ostensibly permanent residents of the city to settle. Being based in the city long-term did not necessarily guarantee stable or higher amounts of employment, either. It soon became apparent that for many workers, it was their liminal status that had kept them in work - with locals reporting around three days a week - half the number worked by migrant interlocutors. Attempting to make a more permanent life in the city was therefore a highly risky business - potentially amounting to trading one kind of precarity for another.

Women's urban mobility was further subject to the tight regional and familial clusters which often dominated on-site and labour-camp life. There was a tendency to reproduce the social norms of the village, at times restricting their physical movement beyond the immediate locality. Urban residence often facilitated a greater desire for control, since the city is subject to stereotypes by rural migrants as sexualised and corrupting spaces for women who work and reside there (Roy, 2003; Patel, 2010; Dalmia, 2012; Phadke, 2013). For instance, on Praveen's site, it was the men who went shopping weekly, because the market (a bus-ride away) was deemed too far for the women to travel. This meant that Hemavathi, Lingamma and their two children seldom ventured outside of the building and its surrounding area. It also meant they did not have ready access to the money they made, as their husbands received their wages. Moreover, since they moved from site to site, Hemavathi and Lingamma's knowledge of Bengaluru was little better than their children's, despite the fact they had been coming for years. "The city is scary", Hemavathi confided. The urban ambivalence utilised by employers to retain workforces by no means went away over time.

Global labour Journal, 2019, 10(1), Page 27 
For Hemavathi and Lingamma, living on site thus restricted the possibility of any potential interactions with urban networks that may have enabled access to vital information, civic amenities and alternative jobs. However, while they were unable to travel far from the confines of the construction site, their freedom of movement was not necessarily different from what it had been in the village. There, men could own and rent bicycles (if they had the means to do so), and thus travel for outside work - a practice forbidden to women, who were restricted to working the fields in the immediate locality. ${ }^{8}$ In contrast, for women who had permanently settled in Bengaluru, it was necessary to work outside of the immediate locality, enabling greater levels of physical mobility and a higher knowledge of urban geography.

While the women of the Thimmaiah campus experienced an ostensibly wider urban milieu than Hemavathi and Lingamma, it is important to note that a number had not travelled beyond the immediate micro-locality of work and settlement. However, younger women such as Shivu and her cousin Shubha, both unmarried, would often walk to and from work unescorted by their male kin, talking and laughing. Indeed, I once ran into them both on their way back from the local market, their arms laden with bags of vegetables. While seemingly insignificant, this event also signified that they were able to handle at least some of their own money, as well as enjoying a degree of familiarity with the immediate locality. Living in the same area for a number of years had also created alternative employment opportunities, with some of the younger women not working construction but finding domestic work in surrounding apartments, opening up incremental but important avenues to additional income. Untypical of migrant settlements, some of the children were also attending nearby schools.

In contrast, while Praveen's workers had been with him for some years, none of the children on site attended school or anganwadis (nursery schools). As Suraj, Hemavathi's husband, stated, "I would like to send them to school, but we'll need someone to pick them up and drop them ... Our work sometimes goes on until eight in the evening". It was Suraj's ambition that, once his son was old enough, he would attend school in the village, since the consequences of no education were apparent: "If we get them to study, they'll end up with good jobs; if we don't or we pull them out of school too early, they'll end up doing the same work we're doing", he concluded. The structural limitations of informal employment and labour migration thus had the propensity to reproduce themselves across generations, as Suraj recognised. As a result, the children on site were often listless and under-stimulated, suffering from long spells of boredom and accidents between helping their parents by performing their tasks in miniature.

As Veena Das and Shalini Randeria (2015: S6) have illustrated, slum communities, like the city, are a "dynamic entity" in which "heterogeneity of the low-income localities in terms of control over assets or access to political connections translates into different outcomes". Similarly, the heterogeneity of building sites, scale and overall employment conditions for migrant construction workers in Bengaluru is correspondingly reflected in the differing responses to and outcomes of these conditions. Within these examples, the links between spatiality, women's autonomy and, significantly, wider forms of urban mobility for migrant families working construction are elucidated. The ways in which wages were paid and the location of accommodation had a clear impact on women's (and children's) movement within the city. The fact that the Thimmaiah

\footnotetext{
${ }^{8}$ Significantly, many scholars have argued that the fields are conceived of as an extension of the domestic realm (Jagori, 2004).

9 As a result, in one of my field sites gender norms, which had previously restricted the movement of women and girls, had correspondingly begun to shift.
} 
women organised their own $\mathrm{chit}^{10}$ fund also attests to the capacity of such spaces for collective organisation: "We started working, getting some money in hand, so we saved it up", Shivu, a teenager who had travelled to work at the Thimmaiah campus with her brother, informed me. Not only did the savings provide a safety net for the women, but money was also sent back to the village each week.

The workers on Praveen's site similarly sent money to relatives in the village on a frequent basis. In this way, the city served as a space in which crucial lifecycle events located in the village could be fulfilled, as Hemavathi attested: "We have to get the young ones married, we have to build houses, so we take loans, and then there's no savings, so we come here". Pun and Huilin (2010: 504) claim that nostalgia for the village among migrant workers "could be understood as a "weapon of the weak' [through which] 'Home' becomes their imaginary anchor to life". Indeed, Hemavathi and Lingamma, and their daughters Eramma and Rangamma, would often talk of the village fondly, with Lingamma once declaring, "Our village is better than here". For the girls it was associated with open space, safer places to play, school and their favourite festivals. Yet to be able to partake in village life, they also had to spend a great amount of time away from it.

For the women on the Thimmaiah campus, however, more and more residents from the village were now flowing into the urban settlement. Devamma, Shivu's grandmother, estimated that up to three members per village household were now frequently residing there, and more were coming. "If they come here it'll feel like our entire village is here, so that makes me happy", she stated. Nevertheless, when I asked Shivu how she liked the city, she replied: "There's nothing to like; we work here. We have to work if we're back home, we have to work if we're here. People back in the village think that if we come to Bangalore, we'll earn a lot of money, but they don't understand how hard we have to work here". For Shivu, who unlike her grandmother had a lifetime of labour in front of her, both localities were presented as interchangeable workplaces, although the influx from her village indicated that agricultural work was increasingly diminished as a sustainable livelihood there. ${ }^{11}$

Migrant populaces may often conceive of extra-locational futures, "bound up with ... senses of prospective geography", within which lie "culturally situated imaginings of elsewhere(s)" (Bunnell, Gillen and Ho, 2017: 5). The location of such futures is further influenced by the varying conditions workers experience, both within the city and the village. For the families of Praveen's site, their continued movement between the various construction sites of the city was largely centred around futures built upon the idea of intermittent but enduring returns to the village. For some workers, however, ongoing movement between both urban and rural locations had begun to alter perceptions of "home", and the fabric of envisioned elsewheres. Shubha, Shivu's cousin, perhaps best articulated the ambivalence created by the continued movement between the two locations when she stated, "When I go there, I feel like coming back here, and when I'm here I feel like going there. Both places feel like home now". As Pun and Huilin (2010) illustrate, and as Shubha and Shivu's answers indicate, younger migrants especially may experience frustration and ambivalence upon realising there are inadequate opportunities in the village and city to sustain them long-term, and their lives must be divided across both.

\footnotetext{
10 Savings group.

11 While Raichur, the district Shivu is from, may be positioned between two significant rivers (the Krishna and the Tungabhadra), it suffers from poor irrigation and failed monsoons. It has recently been named in the top 100 "most backward districts" in India by the central government (Suraksha, 2018).
} 


\section{The Gender Determinants of Industry Mobility: Female Roles in Construction}

While the previous section explored how spatiality and residence informed women's urban mobility, this final section examines how gendered hierarchies inherent within construction work impact vocational mobility. As Connell (2005: 55) states, "Emphasizing the masculinity of industrial labour has been both a means of survival, in exploitative class relations, and a means of asserting superiority over women". Acknowledging the low status of female workers and incidents of gender discrimination within the industry (V. Shah, 1996; Parry, 2014; Breman, 2016), I will argue that the position women occupy within the construction industry constitutes a further form of the domestic sphere - largely discounting them as productive workers.

Conversely, societal gender norms meant that although women were viewed as possessing fewer vices than men by employers within construction, this did not lead to any preference for their employment. As indicated by inherent contradictions within the statements of site owners when describing women, while they were portrayed as more docile and less likely to skip work, drink or cause trouble on site, they were also perceived as less efficient. Praveen praised the strength of women as workers and mothers, telling me, "the women who work out here are really, really strong, you know? From nine to six they help their husbands in carrying all the stuff, giving all the stuff, and like big, big blocks of cement ... sand ... and then at the end of the night, they go home and cook, they take care of their families". However, upon further questioning concerning women's static roles within the industry, he returned to a familiar trope, partly contradicting his earlier statement: "Men are more efficient at doing that work. It's not a gender bias, it's true. So we prefer to have more than women because it's a hard work and we don't like making women work hard, you know?"

While studies attest to the strength and skill of female construction workers (Madhok, 2005; Choudhury, 2013; Thenguzhali and Veerachamy, 2015), they remain largely underplayed and diminished by employers. Any perceived qualities women were deemed to hold were often dismissed in favour of the established industry hierarchies and assertions of their apparent lack of motivation: "Of course they can do it but I feel they don't train themselves - they don't want to do that for themselves", Praveen informed me. Such comments obfuscate the fact that male members of the industry simply do not and will not accommodate women in higher-skilled areas, as one woman elucidated: "I would like to learn but there is no one to teach me". Whereas unskilled male workers had the potential to learn a trade and work their way up, women were routinely discriminated against, unable to rise above their positions (V. Shah, 1996; Vaid, 1999; Choudhury, 2013; Parry, 2014; Breman, 2016). In the rare cases they did, such as the case of one local unionand NGO-backed initiative to teach women masonry; they were later refused employment as masons, returning to work as helpers ${ }^{12}$ (Sany, 2016; Sudhan, 2016). As one woman worker noted, "If we learn anything else, we won't get jobs".

As Soumhya Venkatesan (2010: 158) posits, "the acquisition of a skill is embedded in larger social knowledge about the value of the skill based on ideas about the body, gender, identity, politics, and economics". As a result, "Acquiring, utilizing, or depending upon a skill positions individuals or groups in particular ways, not necessarily of their choosing" (Venkatesan, 2010: 158). The devaluation of manual labour coupled with the distinctly gendered lack of industry mobility thus has the potential to produce internalised self-doubt among women concerning not only their abilities but also alternate pathways of vocational mobility. This was perhaps best reflected in some

\footnotetext{
${ }^{12}$ It should be noted that this form of gender discrimination is not restricted to India but was also encountered by Eisenberg (1998) in her research of journeywomen within the United States in the 1980s and 1990s.
} 
of the answers that followed when I asked women working construction what else they could do for work: "This is all we know how to do", came one such reply.

Such prejudices were also reflected in salaries. Despite the fact that Hemavathi and Lingamma performed similar and often the same roles as their husbands - lifting, fetching water, sweeping, breaking stones and mixing cement - they were paid 250 rupees per day, 100 rupees less than the men, consistent with the gendered pay gap across the construction industry in India. Migrant women also found themselves at the very bottom of the salary scale, typically receiving lower pay than their local female counterparts. ${ }^{13}$ Their salaries were often paid to their husbands rather than to them directly, adding a similar level of concealment to the monetary value of their work in construction as to their work in the home. As was the case for Hemavathi and Lingamma, this inevitably impacted their financial and overall urban mobility. Local women, in contrast, were more likely to be paid directly since they did not always work on the same sites as their husbands, and were at times the sole breadwinners of the household.

One prevalent feature in women's lives in construction, although rarely discussed openly, was sexual harassment and exploitation. Although the potential of construction sites and other such task-scapes to provide spaces for experimentation and freedom outside of the usual social and familial milieu should be recognised (A. Shah, 2006), it is equally important to note that in India working women's associations with these sites feed classist and casteist discourses of sexual impropriety. As a further reinforcement of such hierarchies, women desperate for work were at times required to provide sexual services to maistris. In this way, Parry (2014: 1251) claims, lowercaste working-class women "are revealed as 'corrupt' and 'impure', and the men as failing in their duty to provide and protect". Such associations inevitably impact familial honour and perpetuate gender discrimination. Women living on site were thus placed at a considerably higher risk of unwelcome sexual advances.

Nonetheless, spaces of work and home - whether separate or interchangeable - may also become a means of addressing industry inequalities, even if simultaneously upholding them. Recognising the obstacles of gender discrimination, it is important to acknowledge the utilisation of domestic spaces by grassroots unions as a way of organising settled female workers in Bengaluru. One union achieved this by visiting women's homes and holding meetings in their localities significant, as they are often excluded from union spaces due to their perceived unavailability. Attempts by the same union to lobby for equal pay on the basis that women performed both construction and household work, however, revealed a curious tension - illuminating their unpaid productivity in the domestic realm, as Praveen's earlier statement also highlighted, while failing to acknowledge their equal status to male workers. Such efforts, at the very least, generated greater awareness, with some of the younger male union members taking note, informing me: "They [women] have to work outside and then come home and cook; they have a lot of problems, too. ... They [women] need to be paid the same wage because they do everything we do, except carry the cement bags. They work just as hard as us".

As Picherit (2012) and Parry (2014) have also evidenced, there are instances when women workers would attempt to utilise the masculinity of the construction industry, drawing upon prevalent discourse of male efficiency and aggression: "I've done everything men are doing now, and I've fought for my pay; if they say something, I tell them to pay me first and then talk. I've never not gotten paid for my work!' One former worker declared regretfully that the same leverage and mannerisms that she had employed in construction work were not available to her in her current role within domestic work. Nevertheless, for longer-term vocational mobility, it is

\footnotetext{
13 This was typically around 50 rupees less per day, although it varied from site to site.
} 
undeniable that female construction workers had fewer options and resources to draw upon than men. For migrant women, this was compounded by their transitory status, and trade unions remain largely inflexible in reconceiving the traditional spaces of organisation, which often exclude female and migrant workers (Fernandes, 1997; Breman, 1999; Lindberg, 2001; Roy, 2003), even if, as evidenced by the Thimmaiah workers, they have them in their sights. However, as Smith and Pun (2006) have highlighted, and as this article has also illustrated, migrant workers living in workprovided accommodation did organise among themselves, converting spaces of exploitation in ways neither envisioned nor desired by employers. Even if such efforts, like the strike participated in by Hemavathi and Lingamma, may not always prove successful, they remain significant as both an acknowledgment and contestation of the precarious conditions of the industry and urban life itself.

\section{Conclusion}

As this article illustrates, many workers continue to inhabit an ambivalent status betwixt and between rural and urban lives and livelihoods. Within these contexts, there are myriad ways through which conditions of construction work and accommodation, gender norms and the urban environment may interact to restrict overall mobility for women workers and their families. In spite of the intersectional nature of these forces, varying strategies might be drawn upon by women migrant workers and their families to counter them.

The reason many came to the city was not to find a home, but to sustain life in the village which for some, as the exodus from Shivu's village signified, was becoming increasingly harder. Nevertheless, city livelihoods in construction do prove productive for rural populaces, as both Picherit (2012) and Pattenden (2012) note. For many families, circular migration enables the fulfilment of aspirations and objectives which largely remain rurally rooted - the paying off of agricultural loans; the marking of lifecycle events; getting one's children married; and in their most basic form, the sustenance of one's family. Migrant families working construction are all too aware that to achieve these objectives they must sacrifice others - the education of their children, their health and safety; and the provision of comfortable shelter for the family unit. For migrant women in particular, such sacrifices were accompanied by the heightened risk of sexual harassment, assault and exploitation.

Structural limitations including the gendered and timely distribution of wages and the type and location of workers' accommodation clearly influenced a family's movement - or the lack thereof - through differing aspects of the urban milieu. However, though work and living spaces had the potential to restrict family mobilities, they could also be utilised for various purposes. Forms of worksite accommodation, while serving as spaces of exclusion and control, also became sites in which productive networks and practices could be forged - whether for savings groups, strike action or finding alternative means of employment and education.

Significantly, even for those who have begun locating elusive pathways of urban mobility, this did not necessarily foster a greater feeling of belonging within Bengaluru - nor was this something the city invited. Sending money back to the village and ensuring debts were paid off there was, for both groups, a means of hedging one's bets. The village thus remains the centre of labour's reproduction - while the nature of urban employment and living conditions continue to exclude migrant populaces from claiming state resources or the same rights apportioned to settled workers (Mollona, De Neve and Parry, 2009; Pun and Huilin, 2010; Breman, 2016). In this way, the urban construction industry continues to cultivate and maintain a floating supply of labour in Bengaluru - ever ready to ensure the city's development while remaining largely excluded from it. 


\section{REFERENCES}

Action Aid (2017) Invisible Work, Invisible Workers: The Sub-economies of Unpaid and Paid Work: Action Research on Women's Unpaid Labour. https://www.actionaidindia.org/publications/invisible-workinvisible-workers> [accessed 30 November 2018].

Agarwala, R. (2013) Informal Labor, Formal Politics, and Dignified Discontent in India. Cambridge: Cambridge University Press.

Amrith, S.S. (2011) Migration and Diaspora in Modern Asia. Cambridge: Cambridge University Press.

Baruah, B. (2010) Women and Globalisation: Challenges and Opportunities facing Construction Workers in Contemporary India. Development in Practice, 20(1): 31-44.

Bhalla, N. (2015) Building India's Cities, Silent Workforce of Women goes Unrecognized. Reuters. $<$ https://www.reuters.com/article/us-india-women-construction/building-indias-cities-silentworkforce-of-women-goes-unrecognized-idUSKBN0KL00920150112> [accessed 1 December 2018].

Bhasthi, D. (2017) City of Burning Lakes: Experts Fear Bangalore will be Uninhabitable by 2025. The Guardian, 1 March 2017. < https://www.theguardian.com/cities/2017/mar/01/burning-lakes-expertsfear-bangalore-uninhabitable-2025> [accessed 5 January 2018].

Breman, J. (1996) Footloose Labour: Working in India's Informal Economy. Cambridge: Cambridge University Press.

Breman, J. (1999) The Study of Industrial Labour in Post-colonial India - The Formal Sector: An Introductory Review. Contributions to Indian Sociology, 33(1-2): 1-41.

Breman, J. (2016) On Pauperism in Present and Past. New Delhi: Oxford University Press.

Bunnell, T., J. Gillen and E.L. Ho (2017) The Prospect of Elsewhere: Engaging the Future through Aspirations in Asia. Annals of the American Association of Geographers, 1-17. DOI: 10.1080/24694452.2017.1336424.

Ceresna-Chaturvedi, L., and A. Kumar (2015) Study on Labour Rights Violations and the Availability and Effectiveness of Grievance Mechanisms in the Construction Sector in Bangalore. Bengaluru: CIVIDEP, India.

Choudhury, T. (2013) Experiences of Women as Workers: A Study of Construction Workers in Bangladesh. Construction Management and Economics, 31(8): 883-898.

Connell, R.W. (2005) Masculinities. Second edition. Berkeley: University of California Press.

Construction Industry Development Council (CIDC) (2012) 12 th Five Year Plan (2012-2017). $<$ http://www.cidc.in/new/overview.html> [accessed 28 November 2018].

Cross, J. (2014) Dream Zones: Anticipating Capitalism and Development in India. London: Pluto Press.

Dalmia, A.J. (2012) Strong Women, Weak Bodies, Muted Voices. Economic and Political Weekly, XLVII (2627): $249-255$.

Das, V. and S. Randeria (2015) Politics of the Urban Poor: Aesthetics, Ethics, Volatility, Precarity. Current Anthropology, 56(S11): S3-S14.

De Haan, A. (1999) The Badli System in Industrial Labour Recruitment: Managers' and Workers' Strategies in Calcutta's Jute Industry. Contributions to Indian Sociology, 33(1\&2): 272-301.

Devi, K. and U.V. Kiran (2013) Status of Female Workers in the Construction Industry in India: A Review. IOSR Journal of Humanities and Social Science, 14(4): 27-30.

Eisenberg, S. (1998) We'll Call You If We Need You: Experiences of Women Working Construction. New York: Cornell University Press.

Institute of Human Development (2014) India Labour and Employment Report 2014: Workers in the Era of Globalization. New Delhi: Academic Foundation of New Delhi and Institute of Human Development.

Fernandes, L. (1997) Producing Workers: The Politics of Gender, Class and Culture in the Calcutta Jute Mills. Philadelphia, PA: University of Pennsylvania Press. 
Jagori (2004) Rights and Vulnerabilities: A Research Study of Migrant Women Workers in the Informal Sector in Delhi. New Delhi: Jagori.

Jain, D. (2016) Circular Migration is Holding Back Urbanization. Live Mint, 23 November 2016. $<$ http://www.livemint.com/Politics/p919OfhAoycxqPq9wShSmI/Circular-migration-is-holdingback-Indias-urbanization.html> [accessed 6 September 2017].

Jatrana, S. and K.S. Sangwan (2004) Living on Site: Health Experiences of Migrant Female Construction Workers. Asian and Pacific Migration Journal, 13(1): 61-88.

Goldman, M. (2011) Speculating on the Next World City. In Worlding Cities, Asian Experiments and the Art of Being Global, edited by A. Roy and A. Ong. Hoboken, NJ: Wiley-Blackwell.

Gopalan, K. (2010) Torn in Two: The Tale of Two Bangalores: Competing Discourses of Globalization and Localization in India's Informational City. Dharma: Bhavan's International Journal of Business, 4(2): 83103.

Kamath, R. and S. Ramanathan (2017) Women Tea Plantation Workers' Strike in Munnar, Kerala: Lessons for Trade Unions in Contemporary India. Critical Asian Studies, 49(2): 244-256.

Kerur, B. (2011) Karnataka Population Growth Slows, Bangalore Gets More Crowded. Live Mint, 7 April 2011. < http://www.livemint.com/Politics/RJ1Gt5Q1JkPXaMQSBhvPyL/Karnataka-populationgrowth-slows-Bangalore-gets-more-crowd.html> [accessed 7 January 2018].

Khanijow, S. (2018) Why Women Construction Workers Will Continue to Deliver by the Roadside. The Wire, 28 April 2018. < https://thewire.in/women-construction-workers> [accessed 1 December 2018].

Lakshmi, R. (2013) Bangalore's Reality Lags Behind Image. The Washington Post, 29 April 2013. $<$ https://www.washingtonpost.com/world/asia pacific/bangalores-reality-lags-behindimage/2013/04/29/5825aa98-ace5-11e2-a8e6-b6e4cc7c49d1 story.html?utm term=.f7 de0a96888bc $>$ [accessed 2 January 2018].

Lindberg, A. (2001) Class, Caste, and Gender among Cashew Workers in the South Indian State of Kerala 1930-2000. International Review of Social History. 46: 155-184.

Madhok, S. (2005) Report on the Status of Women in the Construction Industry. New Delhi: National Commission for Women. < http://ncw.nic.in/pdfreports/women $\% 20$ workers $\% 20$ in $\% 20$ construction $\% 20$ industry .pdf> [accessed 9 May 2018].

Mobile Crèches (2011) Construction Industry in India. $<$ http://mobilecreches.org/pdf/Construction\%20Industry.pdf $>$ [accessed 5 March 2016].

Mollona, M., G. de Neve and J. Parry (editors) (2009). Industrial Work and Life: An Anthropological Reader. Oxford: Berg.

Ong, A. (2006) Neoliberalism as Exception: Mutations in Citizenship and Sovereignty. Durham, NC: Duke University Press.

Parry, J. (2014) Sex, Bricks and Mortar: Constructing Class in a Central Indian Steel Town. Modern Asian Studies, 48(5): 1242-1275. Doi: 10.1017/S0026749X1400002X.

Patel, R. (2010) Working the Night Shift. Stanford, CA: Stanford University Press.

Patel, R. and J. Pitroda (2016) The Role of Women in Construction Industry: An Indian Perspective. India Journal of Technical Education, Special Issue for ICWSTCSC (2016): 17-23.

Pattenden, J. (2012) Migrating Between Rural Raichur and Boomtown Bangalore: Class Relations and Circulation of Labour in South India. Global Labour Journal, 3(1): 163-190.

Phadke, S. (2013) Unfriendly Bodies, Hostile Cities. Economic and Political Weekly, XLVIII(39): 50-59.

Picherit, D. (2012) Migrant Labourers' Struggles between Villages and Urban Migration Sites: Labour Standards, Rural Development and Politics in South India. Global Labour Journal, 3(1): 143-162.

Pun, N. and L. Huilin (2010) Unfinished Proletarianization: Self, Anger, and Class Action among the Second Generation of Peasant-Workers in Present-day China. Modern China, 36(5): 493-519. 
Rahul. (2014) Participation of the Female Workers in the Construction Industry in India: A Review. $<$ https://ssm.com/abstract $=2509916>$ [accessed 29 November 2018].

Raj, J. (2018) Teabelts of the Western Ghats, Kerala. In Ground Down by Growth: Tribe, Caste, Class and Inequality in Twenty-first-century India, edited by A. Shah, J. Lerche, R. Axelby, D. Benbabaali, B. Donegan, J. Raj and V. Thakur. London: Pluto Press.

Roy, A. (2003) City Requiem, Calcutta: Gender and the Politics of Poverty [eBook version]. Minneapolis: University of Minnesota Press.

Salve, H. (2013) How India's Construction Workers Get Gypped of Their Due. India Spend, 5 September 2013. < http://archive.indiaspend/com/investigations/how-indias-construction-workers-get-gyppedof-their-due-51414> [accessed 2 December 2018].

Sany, P. (2016) KSCWCU [personal communication], Bengaluru.

Searle, L.G. (2016) Landscapes of Accumulation: Real Estate and the Neoliberal Imagination in Contemporary India. Chicago, IL: University of Chicago Press.

Shah, A. (2006) The Labour of Love: Seasonal Migration from Jharkhand to the Brick Kilns of other States in India. Contributions to Indian Sociology, 40(1): 91-118.

Shah, A., J. Lerche, R. Axelby, D. Benbabaali, B. Donegan, J. Raj and V. Thakur (2018) Ground Down by Growth: Tribe, Caste, Class and Inequality in Twenty-first-century India. London: Pluto Press.

Shah, V. (1996). Women Building Workers: An Area Study in Bombay. NICMAR Research Documents. Mumbai: National Institute of Construction Management and Research.

Shruthi H.M. (2017) Water at Sobha Construction Site Not Fit for Human Consumption: Officials. The Hindu, 31 December 2017. <https://www.thehindu.com/news/cities/bangalore/water-at-sobhaconstruction-site-not-fit-for-human-consumption-officials/article22339841.ece $>\quad$ [accessed 25 September 2018].

Smith, C. and N. Pun (2006) The Dormitory Labour Regime in China as a Site for Control and Resistance. The International Journal of Human Resource Management, 17(8):1456-1470.

Solinger, D.J. (1999) Citizenship Issues in China's Internal Migration: Comparisons with Germany and Japan. Political Science Quarterly, 114(3): 455-479.

Srivastava, R.S. and A. Jha (2016) Capital and Labour Standards in the Organised Construction Industry in India: A Study based on Fieldwork in the National Capital Region of Delhi. Project Report \#2, April. New Delhi: Centre for the Study of Regional Development, Jawaharlal Nehru University.

Sudhan, M. (2016) CIVIC [personal communication], Bengaluru.

Suraksha, P. (2018) Raichur, Yadgir among 100 Backward Districts in India. The New Indian Express, 13 April 2018. <http://www.newindianexpress.com/states/karnataka/2018/apr/13/raichur-yadgir-among100-backward-districts-in-india-1800889.html $>$ [accessed 12 January 2019].

Suri, S. (2000) Yellow Helmets: Worth and Work of Women Workers on Construction Sites in Northern India. Unpublished master's thesis, Massachusetts Institute of Technology, Cambridge, MA.

Thenguzhali, T. and P. Veerachamy (2015) Occupational Health Hazards of Women Construction Workers: A Critical Survey of the Literature. Language in India, 15(8): 288-319.

Vaid, K.N. (editor) (1999) Women in Construction. Mumbai: NICMAR Publication Bureau.

Venkatesan, S. (2010) Learning to Weave; Weaving to Learn ... What? Journal of the Royal Anthropological Institute, 16(S1): S158-S175.

Women in Employment: Globalizing and Organizing (WIEGO) (2019) Statistical Picture.

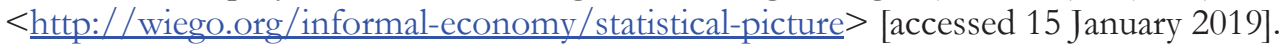




\section{BIOGRAPHICAL NOTE}

REBECCA Bowers is a final-year PhD student at the Social Anthropology Department at the London School of Economics (LSE), where she previously worked as Editor at the LSE South Asia Centre. Her doctoral research focuses on urban mobility for female construction workers in Bengaluru, southern India. It engages with the real estate industry and how practices of urban speculation, accumulation and gender discrimination shape inequality, discounting workers as productive contributors and devaluing (female)manual labour. [Email: R.E.Bowers@lse.ac.uk] 